\title{
Technology in Educational Settings in the Government Polytechnic Institutes of Bangladesh: A Critical Analysis
}

\author{
Md. Abdullah-Al-Mamun \\ Islamic University of Technology \\ Department of TVE \\ Gazipur, Dhaka, Bangladesh
}

\begin{abstract}
The role of education in facilitating social and economic progress has long been recognized and skills and knowledge are the engines of economic growth and social development of any country [1]. And skilled workforces contribute extensively to enhance the national economy of every country. Therefore, government polytechnic institutes of Bangladesh give emphasis to produce skilled technicians for building up a secure national economy. Nowadays technology appears in education as a proficient tool for effective teaching and learning. To make the graduates competent for the global market, polytechnic institutes of Bangladesh require proper integration and utilization of modern technology in the educational setting. This study aims to analyze the current state of affairs of using technology in the government polytechnic institutes of Bangladesh. Different statistical methods were used in this study to analyze the data critically. It was exposed that the use of computers and internet were very much limited in polytechnic institutes. The teachers, administrators and students pointed out that the overall quality of technology service offered by the institution was not up to standard. Moreover, poor infrastructure, lack of training and unavailability of modern technology were persisting simultaneously. Hence the existing situation in the educational settings was found to be a crucial hindrance to digitize Bangladesh and needs proper policy making to overcome the present situation.
\end{abstract}

\section{General Terms}

Educational Technology used in the Government Polytechnic Institutes of Bangladesh

\section{Keywords}

Educational Technology, Teaching-learning, Polytechnic Institutes, Bangladesh

\section{INTRODUCTION}

The present government of Bangladesh includes digitization of the country in its political agenda in order to accelerate a Digital Bangladesh movement [2]. In this regard, the Government of Bangladesh has already emphasized the integration of technology in all sectors of the country including education. The skilled workers and technicians play a key role in every sector of the economy of Bangladesh. To produce skilled technicians, there are mid-level technical and vocational training systems in the country [3]. According to the official website of the Director of Technical Education [4], the number of Government Technical Education institutions in Bangladesh is 117. At this moment, 6 projects are in operation, and after completion of these projects, few more institutions of different levels will be added in a few years. But in terms of technology integration, the fact is that Bangladesh is one of the countries in the world with very poor Information and Communication Technology (ICT) infrastructure [5]. However, in accordance with the requirements of information age, providing educational support to the individuals using advanced technology is an indispensable part of education [6]. In this respect, many governments have developed plans to intensify their investments regarding technology integration in education [7]. Bangladesh is not an exception. Formal education using computers first started in 1984 with the foundation of Computer Science and Engineering Department in Bangladesh University of Engineering and Technology. ICT education thereafter gradually extended to the bachelor's degree, higher secondary and secondary school levels [8]. The government plans to make ICT education compulsory at secondary level by 2013 and at primary level by 2021 . Nationally, the technology integration process in primary education received a significant boost with the inception of the second Primary Education Development Program-II (PEDP II), a two-year (2009-2011) government run initiative [9].

The government formulated a National Education Policy which recommended compulsory computer courses from the secondary level of education. Already the Board of Intermediate and Secondary Education, Dhaka introduced computer science as an optional subject in 1991 [8]. Besides polytechnics, Vocational Training Institutes (VTI) and Technical Training Centers (TTC) in Bangladesh are offering training in existing and new skills in line with emerging technologies and demands of the economy [10]. In addition, there are 37 government polytechnic institutes and 64 technical colleges in different parts of the country, where information technology is part of the core curriculum. From 2009, Computer Science has been included as a mandatory subject for the SSC Vocational examination [9]. Recently Bangladesh has made considerable progress in integrating technology in the public sector including education [1].

But technology integration in educational settings requires an implementation plan. Without a needs-analysis, suitable planning and management activities, projects are condemned to slow progress or absolute failure [11]. Levine [12] emphasizes the importance of having a plan that is based on real institutions needs and one that is realistic, feasible, and effective. Papo [13] notes that success will require an adjustment in the work processes with maximizing learning, by means of the most appropriate methods and technologies, as a primary goal. Research has revealed that, if properly implemented, learners can gather the pedagogical benefits of technology in the classroom. Experts today increasingly advocate the implementation of the constructivist model of learning rather than of the traditional instructivist model [14, 15]. Twigg [16] said "colleges and universities must move their focus from improving teaching to improving student learning. Once learning becomes the central focus, the important question is how best to use all available resources- 
including faculty time and technology - to achieve certain learning objectives." However, it is necessary to know the philosophy and different aspects of integrating technology in the educational settings. The researchers have developed various points of views about the relation between education and technology. Szabo [17] focuses on the technical and nontechnical aspects of the relation between education and technology. He further says that use of technologies such as software, hardware, telecommunication and digital instruction tools in education is the technical aspect of the problem whereas variables such as vision, objective, strategy, education and infrastructure concern its nontechnical aspect.

Technology should be used as a tool to support educational objectives such as skills for searching and assessing information, cooperation, communication and problem solving - which are important for the preparation of children for the knowledge society [18]. Recent studies proved that technologies allow students to work more productively than in the past, but the teachers' role in technology-rich classrooms is more demanding than ever [19]. The number of researchers indicates that teachers should adopt technology in instruction for better teaching [20,21, and 22]. Thus the teachers of the polytechnic institutes should be conscious about the continuous development of technology in education, which offers students an inventive approach to experience learning. For today's students to acquire complex problem-solving, critically thinking, and concise communication skills in appropriately technology-assisted contexts, the teacher will have to approach teaching differently in order to bring their own proficiency to bear in meeting students' learning needs [23]. Donna [24] notes: "Pouring a solid foundation of good pedagogical design before adding on the layer of technology can become a critical factor in the success rate of technology integration." Indeed, within an interactive lecture format there are various ways to guide students' use of the technologies that they often have at their fingertips [25]. Natriello [26] argues that learning will increasingly have effect on multiple settings and contexts, that are less discipline-bound and that make more effective use of the new technology tools which support knowledge creation, knowledge gathering, and knowledge sharing inside and outside of institutional settings. The promising practice therefore, is a blending of classroom and technology. Technologies are enablers, and when put in the hands of good teachers they will improve both their cognitive and behavioral learning skills as they work [27].

Technology is one of the productive tools which are not effectively introduced in the polytechnic institutes of Bangladesh till now. Ali [8] reported that ICT achievement in the education sector in Bangladesh is still now in the beginning stage. For example the community of Rajshahi University, the second largest university in Bangladesh, has derived some benefits from internet access though nearly half of the responsible authorities of the various sectors are not satisfied with the existing facilities owing to several constraints [28]. There is no formal statistics in Bangladesh on human capacity in use of technology; however, the other correlated information (computer penetration rate) hints that the knowledge about use of computer is still low, despite high growth [29]. Poor training infrastructure, lack of quality trainers, fragmented government ownership are some of the major issues hindering the effective development of information technology in vocational education infrastructure in Bangladesh [9].

Almost no significant research has been conducted about the integration and uses of technology in polytechnic institutes of Bangladesh. Based on the literature and practitioner experience, Leggett \& Persichitte [30] identify several categories of barriers to technology integration, such as: expertise, access, resources, and support. This study examined and discussed highly about these aspects in educational settings of different polytechnic institutes. Specifically, this study focuses on the use of technology by the teachers in different directions, students and administrators and the barriers of adapting technology in the educational settings.

\section{RESEARCH METHODOLOGY}

Six Government Polytechnic Institutes were selected as sample for this study. These institutes were chosen based on the geographical location where technological advancement seems to be most available. The polytechnics were selected from the cities as well as technologically advanced towns of the countries and classified as follows -

Cluster (X): Polytechnics in Cities

Cluster (Y): Polytechnics in Towns

Data were collected from the teachers, administrators and students. Principals, Vice Principals and Heads of the departments were considered as administrator in this study. Teachers and students from different departments were randomly selected. Three different structured questionnaires were developed to collect the data from teachers, administrators and students respectively. The main focus was given to the teachers' side. The validity of the questionnaires was confirmed through experts' opinion and by pilot study on a small group of teachers and students in Mymensingh polytechnic. Each item of the questionnaires was evaluated and adapted after pilot study. The following table shows the responses from the target population in particular under each cluster-

Table-1: Responses from the questionnaires

\begin{tabular}{|c|c|}
\hline Cluster $(\mathbf{X})$ & Cluster (Y) \\
\hline $\begin{array}{ll}\text { - } & \text { Dhaka Polytechnic } \\
\text { Institute } & \end{array}$ & $\begin{array}{ll}\text { - } & \text { Barishal Polytechnic } \\
\text { Institute } & \end{array}$ \\
\hline $\begin{array}{l}\text { - Chittagong Polytechnic } \\
\text { Institute } \\
\end{array}$ & $\begin{array}{lll}\text { - } & \text { Rangpur } \\
& \text { Institute } & \\
\end{array}$ \\
\hline $\begin{array}{lll}- & \text { Khulna } & \text { Polytechnic } \\
& \text { Institute } & \\
\end{array}$ & $\begin{array}{l}\text { - Mymensingh Polytechnic } \\
\text { Institute }\end{array}$ \\
\hline $\begin{array}{l}\text { Teacher: Sample = 200; } \\
\text { Responses: } 77 \\
\text { Administrator: Sample = } \\
\text { 31; Responses: } 20\end{array}$ & $\begin{array}{l}\text { Teacher: Sample = 80; } \\
\text { Responses: } 53 \\
\text { Administrator: Sample = } \\
\text { 25; Responses: } 12\end{array}$ \\
\hline $\begin{array}{l}\text { Student: Sample = } 60 ; \\
\text { Responses: } 47\end{array}$ & $\begin{array}{l}\text { Student: Sample = } 60 \text {; } \\
\text { Responses: } 60\end{array}$ \\
\hline
\end{tabular}

Total Responses $(\mathrm{N})$ : Teacher $=130 ;$ Administrator $=32$; Students $=107$

Variation in sampling occurred due to the availability of the target population during the data collection. Moreover the number of teachers and administrators are more in the cities. The return rate of the questionnaires was found $46.43 \%$ for the teachers, $57.14 \%$ for the administrators and $89.17 \%$ for the students respectively.

\subsection{Statistical Method Used For This Study}

Responses from the sample groups were collected, calculated and analyzed in different aspects to reach a meaningful conclusion. Different statistical methods were used for this purpose. 


\subsubsection{Coefficient of correlation:}

To calculate the coefficient of correlation (without calculating deviation), Pearson's product moment method [31] was used. Then null hypothesis was set up to test the result at 0.05 level of significance. The formulae are -

$$
r=\frac{N \sum X Y-\sum X \sum Y}{\sqrt{\left[N \sum \mathrm{X}^{2}-\left(\sum \mathrm{X}\right)^{2}\right]\left[\mathrm{N} \sum \mathrm{Y}^{2}-\left(\sum \mathrm{Y}\right)^{2}\right]}} ;
$$

Where, $\mathrm{X}$ and $\mathrm{Y}=$ Raw scores, $\mathrm{N}=$ Total number of cases Degree of Freedom, $d f=(N-2)$

\subsubsection{Significance of difference between means:}

To determine the significance and the direction of the difference between two sample means a directional hypothesis (one-tailed test) was made to justify the difference at 0.05 significance level. Then Standard Error $\left(\sigma_{\mathrm{D}}\right)$ of the differences between two means was determined and standard score $\left(Z_{o}\right)$ was computed to take the decision about the significance and the direction of difference of the means. The following formulae were used in this method-

$$
\begin{gathered}
\text { Standard Score, } Z=\frac{M_{1}-M_{2}}{\sigma_{\mathrm{D}}} \\
=\frac{\text { Differences between means }}{\text { Standard error of differnces between means }} ; \text { and }
\end{gathered}
$$

Standard error, $\sigma_{\mathrm{D}}=\sqrt{\frac{\sigma_{1}^{2}}{\mathrm{~N}_{1}}+\frac{\sigma_{2}^{2}}{\mathrm{~N}_{2}}} ;$ Where $\sigma_{1}$ and $\sigma_{2}=$ Standard deviation of the two samples

\subsubsection{Chi-Square test:}

The nonparametric Chi-Square test on the basis of hypothesis of equal probability is used to determine whether the opinions of the respondents are significant or not. The following formula is used in this regard-

$$
\text { Chi-square, } \chi^{2}=\sum\left[\frac{\left(f_{o}-f_{e}\right)^{2}}{f_{e}}\right] \text {; }
$$

Where, $f_{o}=$ Observed frequency and $f_{e}=$ Expected frequency considered with equal probabilities.

Degree of freedom, $d f=(C-1) *(R-1)$;

Where, $\mathrm{C}=$ Number of columns, $\mathrm{R}=$ Number of rows After obtaining the value of Chi-square from the above formula it was compared with the critical value of Chi-square at 0.05 level of significance. Finally interference was made whether the difference is significant or not to reject or retain the null hypothesis. If, $\chi_{\text {observed }}^{2}>\chi_{\text {critical }}^{2}$; the response will be taken as significant in favor of the statement.

\subsubsection{Null Hypothesis and the level of significance:}

Null hypothesis is the starting point of solving a problem related to the significance of difference. Such a hypothesis always emphasizes that there exists no real difference between two population means and that the difference found between sample means is therefore, insignificant [31]. To find a direction in the differences one-tailed test (directional hypothesis) was made to examine the null hypothesis. To test the Hypothesis, $5 \%$ or 0.05 significance or confidence level was taken in this study. When a hypothesis is rejected at the $5 \%(0.05)$ level, it is said that the chances are 95 out of 100 , that the hypothesis is not true and only 5 chances out of 100 that it is true. The weighted average (WA) based on Likert
Scale ( 5 point scale) has been considered for some items in the questionnaires for further interpretation.

\section{ANALYSIS AND DISCUSSION ON FINDINGS}

The general perception of this study was to find out the state of affairs of the existing technology in the polytechnic institutes and how much they were benefited from it. The study reveals the following findings on different aspects.

\subsection{Existing Technology in the Two Clusters}

To understand the overall scenario of the six polytechnics the

\begin{tabular}{|c|c|c|}
\hline Tools of Technology & $\begin{array}{c}\text { Cluster } \\
(\mathbf{X})\end{array}$ & $\begin{array}{c}\text { Cluster } \\
(\mathbf{Y})\end{array}$ \\
\hline Computer & 260 & 165 \\
\hline Multimedia projector & 12 & 10 \\
\hline OHP & 19 & 13 \\
\hline Printer & 50 & 40 \\
\hline Computer lab & 3 & 3 \\
\hline Scanner & 12 & 4 \\
\hline Digital camera & 3 & 3 \\
\hline Projector & 7 & 3 \\
\hline Television & 59 & 23 \\
\hline $\mathrm{VCR} / \mathrm{VCD}$ & 11 & 7 \\
\hline \multicolumn{3}{|c|}{ Number of Items, $N=10$} \\
\hline \multicolumn{3}{|c|}{$\begin{array}{l}\text { Local area network (LAN) was not available } \\
\text { in both the clusters and use of internet was } \\
\text { very limited as well. }\end{array}$} \\
\hline
\end{tabular}
following data were collected regarding ten most common technology tools and facilities used in the educational settings.

Table-2: Existing technology of the two clusters

The table 2 shows differences in the availability of technology tools between the clusters where polytechnics in cities were technologically more advanced than the polytechnics in towns. However, before a concrete decision made, a null hypothesis was made at 0.05 level of significance to justify whether these differences were significant or not. Pearson's product moment method (without calculating the deviation) formula was used to find the correlation of coefficient.

Table 3: Correlation Between two clusters

\begin{tabular}{c|l|l|l}
\hline $\boldsymbol{N}$ & $\boldsymbol{r}_{\text {observed }}$ & $\boldsymbol{r}_{\text {critical }}$ & Level of Significance \\
\hline 10 & 0.99 & 0.632 & 0.05 \\
\hline \multicolumn{4}{c}{ Result: $r_{\text {observed }}<r_{\text {critical }} ;$ Null Hypothesis is rejected } \\
\hline
\end{tabular}

As Null Hypothesis was rejected, we may safely conclude that the differences between two clusters cannot be attributed to a chance factor. These differences are quite trustworthy and dependable to say that the polytechnics in Cities are more advanced in technology than the polytechnics in towns.

Besides, the local area network (LAN) which seems to be very essential for the educational institution was not available in any polytechnic. The general remark from the table 3 is that the two clusters are not technologically rich enough to meet the educational standard at this level, which is treated as the main stream of producing skilled technicians for the country. 


\subsection{Available Accessibility to Computer and Internet}

Computer and internet are thought to be very important tools of achieving advanced level of skills and expertness nowadays. This is even truer for the technical and vocational education filed. It is observed that more the available facilities more the progress in teaching learning. In this regard the following data were collected with respect to the ease and available access of computer and internet by the teachers and students.

Table-4: Available accessibility to computer and internet in Cities

\begin{tabular}{|c|c|c|c|c|}
\hline \multicolumn{5}{|c|}{ Cluster One } \\
\hline \multirow{2}{*}{$\begin{array}{l}\text { Name of the } \\
\text { polytechnics }\end{array}$} & \multicolumn{2}{|c|}{$\begin{array}{c}\text { Teachers' responses } \\
\text { (Yes) }\end{array}$} & \multicolumn{2}{|c|}{$\begin{array}{c}\text { Students' responses } \\
\text { (Yes) }\end{array}$} \\
\hline & Computer & Internet & Computer & Internet \\
\hline $\begin{array}{l}\text { Dhaka } \\
\text { Polytechnic }\end{array}$ & 20 & 12 & 8 & 1 \\
\hline $\begin{array}{l}\text { Chittagong } \\
\text { Polytechnic }\end{array}$ & 20 & 18 & 20 & 13 \\
\hline $\begin{array}{l}\text { Khulna } \\
\text { Polytechnic }\end{array}$ & 22 & 15 & 15 & 7 \\
\hline $\begin{array}{l}\text { Total } \\
\text { Responses }\end{array}$ & $\begin{array}{c}\mathbf{6 2} \\
(47.69 \%)\end{array}$ & $\begin{array}{c}\mathbf{4 5} \\
(34.61 \%)\end{array}$ & $\begin{array}{c}\mathbf{4 3} \\
(40.19 \%)\end{array}$ & $\begin{array}{c}\mathbf{2 1} \\
(19.62 \%)\end{array}$ \\
\hline
\end{tabular}

It is found from the above table that teachers had more available access on computer and internet than the students. Now the question is whether these differences were significant enough to indicate that teachers got the more advantage on using computer and internet in cluster one? Null hypothesis was made and one-tailed test was used to validate the null hypothesis.

Table-5: Computer Access in Cluster One (One-tailed test)

\begin{tabular}{c|c|c|c|c|l}
\hline $\begin{array}{c}\text { Computer } \\
\text { Access in } \\
\text { Cluster } \\
\text { One }\end{array}$ & $\boldsymbol{M}$ & $\boldsymbol{S D}$ & $\begin{array}{c}\text { Standard } \\
\text { Error } \\
\left(\boldsymbol{\sigma}_{\mathbf{D}}\right)\end{array}$ & $\begin{array}{c}\text { Observed } \\
\text { Score } \\
\left(\boldsymbol{Z}_{\boldsymbol{o}}\right)\end{array}$ & $\begin{array}{l}\text { Standard } \\
\text { Score } \\
\left(\boldsymbol{Z}_{\boldsymbol{c}}\right)\end{array}$ \\
\cline { 1 - 3 } $\begin{array}{c}\text { Teachers } \\
\text { Response }\end{array}$ & 20.67 & 0.33 & 0.297 & 21.34 & 1.65 \\
\cline { 1 - 3 } $\begin{array}{c}\text { Students } \\
\text { Response }\end{array}$ & 14.33 & 1.93 & & & \\
\hline Result: $Z_{o}>Z_{c}$ Null Hypothesis Rejected at 0.05 significance level \\
\hline
\end{tabular}

Table-6: Internet Access in Cluster One (One-tailed test)

\begin{tabular}{c|c|c|c|c|c}
\hline $\begin{array}{c}\text { Internet } \\
\begin{array}{c}\text { Access } \text { in } \\
\text { Cluster } \\
\text { One }\end{array}\end{array}$ & $\boldsymbol{M}$ & $\boldsymbol{S D}$ & $\begin{array}{c}\text { Standard } \\
\text { Error } \\
\left(\boldsymbol{\sigma}_{\mathbf{D}}\right)\end{array}$ & $\begin{array}{c}\text { Observed } \\
\text { Score } \\
\left(\boldsymbol{Z}_{\boldsymbol{o}}\right)\end{array}$ & $\begin{array}{c}\text { Standard } \\
\text { Score } \\
\left(\boldsymbol{Z}_{\boldsymbol{c}}\right)\end{array}$ \\
\cline { 1 - 2 } $\begin{array}{c}\text { Teachers } \\
\text { Response }\end{array}$ & 15 & .894 & 0.342 & 23.39 & 1.65 \\
\cline { 1 - 2 } $\begin{array}{c}\text { Students } \\
\text { Response }\end{array}$ & 7 & 2.61 & & & \\
\hline \multicolumn{6}{c}{ Result: $Z_{o}>Z_{c}$ Null Hypothesis Rejected at 0.05 significance } \\
level
\end{tabular}

Our computed value $Z_{o}$ exceeded the critical value of 1.65 in both the cases. Therefore, it might be taken as significant in both the cases at the 0.05 significance level. Hence the null hypotheses were rejected at the 0.05 level and we could say that these differences were significant and teachers got the more advantage by gaining available access on computer and internet than the student.

Little bit different situation was observed in cluster two. The following table revealed the present scenario of cluster two-

Table-7: Available accessibility to computer and internet in Towns

\begin{tabular}{ccccc}
\hline & \multicolumn{3}{c}{ Cluster Two } & \\
\hline Polytechnics & \multicolumn{2}{c}{$\begin{array}{c}\text { Teachers' Response } \\
\text { (Yes) }\end{array}$} & $\begin{array}{c}\text { Students' Response } \\
\text { (Yes) }\end{array}$ \\
\cline { 2 - 5 } & Computer & Internet & Computer & Internet \\
\hline $\begin{array}{c}\text { Barishal } \\
\text { Polytechnic }\end{array}$ & 11 & 5 & 17 & 6 \\
\hline $\begin{array}{c}\text { Rangpur } \\
\text { Polytechnic }\end{array}$ & 15 & 6 & 19 & 3 \\
\hline $\begin{array}{c}\text { Mymensingh } \\
\text { Polytechnic }\end{array}$ & 18 & 8 & 19 & 5 \\
\hline $\begin{array}{c}\text { Total } \\
\text { Responses }\end{array}$ & $\mathbf{4 4}$ & $\mathbf{1 9}$ & $\mathbf{5 5}$ & $\mathbf{1 4}$ \\
\hline & $(33.85 \%)$ & $(14.62 \%)$ & $(51.40 \%)$ & $(13.08 \%)$ \\
\hline
\end{tabular}

An impressive state of affairs was observed in cluster two that the students were getting more opportunity to use the computer than the teachers. However in case of internet the situation was similar like cluster one. In both the cases we assumed the hypotheses that the differences were significant and these differences benefitted the teachers group. One-tailed test was used again to validate the hypothesis whether these differences were significant or not and to know the actual direction of the differences.

Table 8: Computer Access in Cluster Two (One-tailed test)

\begin{tabular}{r|c|c|c|c|c}
$\begin{array}{r}\text { Computer } \\
\text { Access in } \\
\text { Cluster } \\
\text { Two }\end{array}$ & $M$ & $S D$ & $\begin{array}{c}\text { Standard } \\
\text { Error } \\
\left(\sigma_{\mathrm{D}}\right)\end{array}$ & $\begin{array}{c}\text { Observed } \\
\text { Score } \\
\left(Z_{o}\right)\end{array}$ & $\begin{array}{c}\text { Standard } \\
\text { Score } \\
\left(Z_{c}\right)\end{array}$ \\
\hline \begin{tabular}{r|c|c|c} 
Teachers \\
Response
\end{tabular} & $\begin{array}{c}14.6 \\
6\end{array}$ & 1.15 & 0.179 & -20.50 & 1.65 \\
\hline $\begin{aligned} \text { Students } \\
\text { Response }\end{aligned}$ & $\begin{array}{l}18.3 \\
\text { Result: } Z_{o}<Z_{c}\end{array}$ & $\begin{array}{l}0.35 \\
0\end{array}$ & & & \\
\hline \multicolumn{5}{r}{ Null Hypothesis is Accepted at 0.05 significance } \\
level
\end{tabular}

Table 9: Internet Access in Cluster Two (One-tailed test)

\begin{tabular}{c|c|c|c|c|c}
\hline $\begin{array}{c}\text { Internet } \\
\text { Access in } \\
\begin{array}{c}\text { Cluster } \\
\text { Two }\end{array}\end{array}$ & $M$ & $S D$ & $\begin{array}{c}\text { Standard } \\
\text { Error } \\
\left(\sigma_{\mathrm{D}}\right)\end{array}$ & $\begin{array}{c}\text { Observed } \\
\text { Score } \\
\left(Z_{o}\right)\end{array}$ & $\begin{array}{c}\text { Standard } \\
\text { Score } \\
\left(Z_{c}\right)\end{array}$ \\
\cline { 1 - 4 } $\begin{array}{c}\text { Teachers } \\
\text { Response }\end{array}$ & 6.33 & 0.92 & 0.315 & 5.30 & 1.65 \\
\cline { 1 - 2 } $\begin{array}{c}\text { Students } \\
\text { Response }\end{array}$ & 4.66 & 0.88 & & & \\
\hline Result: $Z_{o}>Z_{c}$ Null Hypothesis is Rejected at 0.05 significance \\
level
\end{tabular}

In the first case our presumed hypothesis was accepted and thus alternately we can say that the differences were significant to give advantage to the students over the teachers. And in case of internet the null hypothesis was rejected and we could say that these differences were significant to benefit the teachers over the students. We may conclude for both the 
clusters that there was an imbalance distribution of technology and it was not equally available to the teachers and students. Afshari et al. [32] state that efficient and effective use of technology depends on the availability of hardware and software and the equity of access to resources by teachers, students and administrative staff. Though Twigg [15] identifies a number of readiness criteria for success and she indicates an institution must use technology strategically for specific academic goals instead of as a general resource equally available to everyone. However, Mumtaz [33] and BECTA [34] reported that a lack of technology availability was a key factor in preventing teachers from using technology in their instruction. Thus, this could be a crucial problem for the harmonic development of the polytechnic institutes.

\subsection{To What Extent the Existing}

\section{Technology Benefits Teachers and Students}

A question was asked to the teachers regarding the use of computer and how they were benefitted from it.

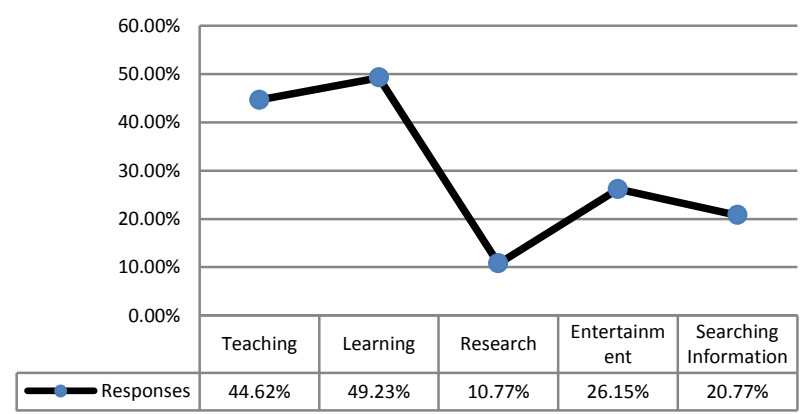

Fig. 1: Extent of using Computer by the teacher (multiple responses were accepted)

The most significant but unpleasant fact emerging form the figure 1 is that the teachers spent less time on computer for research as well as for searching the information which is an essential part of conducting research. Previous study indicates technology plays an integral role in research [35]. The advent of information and communication technology has witnessed a proliferation of research at all levels of education and training [36]. Therefore teachers' position in using technology in research work was not satisfactory at this level of education. However it is a very good sign that the teachers were using computer for teaching and learning in a large amount. Gibbons and Fairweather [37] state that generally teachers use computers not just for the process of teaching and learning but also for a number of other reasons. Research indicates that in terms of teaching and learning, the actual usage of computer by the teachers in classrooms is mainly to impart knowledge, create variety, and to give them the confidence in the process of teaching and learning [38, 39]. Besides, teachers choice to the computer for personal use too that would enable them to engage their free time in a beneficial and fruitful manner [37].

\subsection{Utility and Satisfaction Level of the Existing Technological Tools}

Utilization of available resources maximizes the speed of the progress of an institution. If the resources are limited then there will be demand on more resources for smooth progress. Proper utilization of the technology tools come through motivation and satisfaction which are the key to work. In this regard the following data were observed from the teachers.
The teachers were not satisfied and the existing technologies were not properly used for teaching learning as illustrated through the differences in their opinions in Table 10.

Table-10: Utility and Satisfaction level of the existing technology

\begin{tabular}{l|l|c|c|c}
\hline Statements & \multicolumn{2}{|c|}{$\begin{array}{c}\text { Teachers Opinion } \\
(\mathrm{N}=130)\end{array}$} & $\chi_{\text {observed }}^{2}$ & $\chi_{\text {critical }}^{2}$ \\
\hline $\begin{array}{l}\text { Utility of } \\
\text { the existing } \\
\text { technology }\end{array}$ & Yes & $\begin{array}{c}35 \\
(26.92 \%)\end{array}$ & 27.68 & 3.841 \\
\cline { 2 - 4 } & No & $\begin{array}{c}95 \\
(73.08 \%)\end{array}$ & & \\
\hline $\begin{array}{l}\text { Satisfaction } \\
\text { with the } \\
\text { existing } \\
\text { technology }\end{array}$ & Yes & $\begin{array}{c}34 \\
(26.15 \%)\end{array}$ & 29.56 & 3.841 \\
\cline { 2 - 3 } & No & $\begin{array}{l}96 \\
(73.85 \%)\end{array}$ & & \\
\hline
\end{tabular}

Result: In both the cases Null Hypothesis is Rejected as, $\chi_{\text {observed }}^{2}>\chi_{\text {critical }}^{2}, d f=1$, and level of significance is 0.05

To verify the standings of the teachers' opinions null hypotheses were applied. In both the cases it was found that the differences were significant as the null hypotheses were rejected. Thus it was quite certain that the experimental results were not based on a mere chance factor. In this regard Gunter [40] found that higher education faculty who use a variety of innovative teaching and learning strategies can effectively promote the use of technology by integrating it into their own instruction. Therefore, being prepared to adopt and use technology and knowing how that technology can support student learning must become integral skills in every teacher's professional repertoire [41]. It is obvious that when teachers could utilize the technology effectively in classroom settings then satisfaction comes automatically.

\subsection{Utilization of the Existing Technology and Skill Improvement (Administrators Opinion)}

The similar question on proper use of technology as well as about the skill of the teachers on modern technology was asked to the administrators. The administrators were not persuaded about the proper utilization of the technology but almost everyone was very much indisputable that the teachers need to improve their skill on technology. The following table portrayed their thoughts-

Table-11: Utilization of the existing aids and skill improvement on ICT

\begin{tabular}{l|c|c|c|c}
\hline \multicolumn{1}{c|}{ Statements } & \multicolumn{2}{|c|}{$\begin{array}{c}\text { Administrators } \\
\text { Opinion } \\
(\mathrm{N}=32)\end{array}$} & $\chi_{\text {observed }}^{2}$ & $\chi_{\text {critical }}^{2}$ \\
\hline \multirow{2}{*}{$\begin{array}{l}\text { ICT tools } \\
\text { properly used by } \\
\text { the teacher }\end{array}$} & Yes & $\begin{array}{c}15 \\
(46.86 \%)\end{array}$ & 0.12 & 3.841 \\
\cline { 2 - 3 } & No & $\begin{array}{c}17 \\
(53.13 \%)\end{array}$ & \\
\hline $\begin{array}{l}\text { Need to improve } \\
\text { the skill of using } \\
\text { modern } \\
\text { technology }\end{array}$ & Yes & $\begin{array}{c}28 \\
(87.50 \%)\end{array}$ & \multirow{2}{*}{18} & 3.841 \\
\cline { 2 - 3 } & No & $\begin{array}{c}4 \\
(12.50 \%)\end{array}$ & & \\
\hline
\end{tabular}

Result: In the first case, Null Hypothesis is accepted as, $\chi_{\text {observed }}^{2}<\chi_{\text {critical }}^{2}$;n the second case, Null Hypothesis is rejected as, $\chi_{\text {observed }}^{2}>\chi_{\text {critical }}^{2} ; d f=1$, and level of significance is 0.05 
The experimental results accept the null hypothesis in the first case and prove the differences in the opinions were based on equal probability. Thus the opinions were insignificant and administrators gave their opinions without knowing the truth. But in the second case it is trustworthy to say that the difference was very much significant and the thought of administrators was right. Therefore, the teachers need to be improved in their technical skill on modern aids of teaching learning. Research indicates that the key predictor of technology use is the amount of technology training [42]. Afshari et al [32], states that professional development is necessary for teachers to enable them for effective use of technology to improve student learning. Therefore a frequent training on technology use would favor the teachers in this regard. Albee [43] in her study investigated teachers' technology skills and the expectation of administrators at schools for new teachers to have technology skills. She found a discrepancy between what the administrators expected from the pre-service teachers and the pre-service teachers' actual technology skills. Moreover, positive teacher attitudes toward computers are widely recognized as a necessary condition for effective use of information technology in the classroom [44]. Berner [45] found that the faculty's belief in their computer competence was the greatest predictor of their use of computers in the classroom.

\subsection{Factors Limit the Use of Modern Technology}

It was found according to the teachers that there were four key factors that limit the use of technology which are- a) lack of knowledge, b) lack of skill, c) lack of training and d) unavailability of modern technology. Administrators marked that- a) difficult to find skilled technical personnel, b) expenditure higher than expected and c) latest technology was not given prefer over the traditional tools by the teacherswere the key barriers for the proper utilization of technology in the institutions. The following figures support their views.

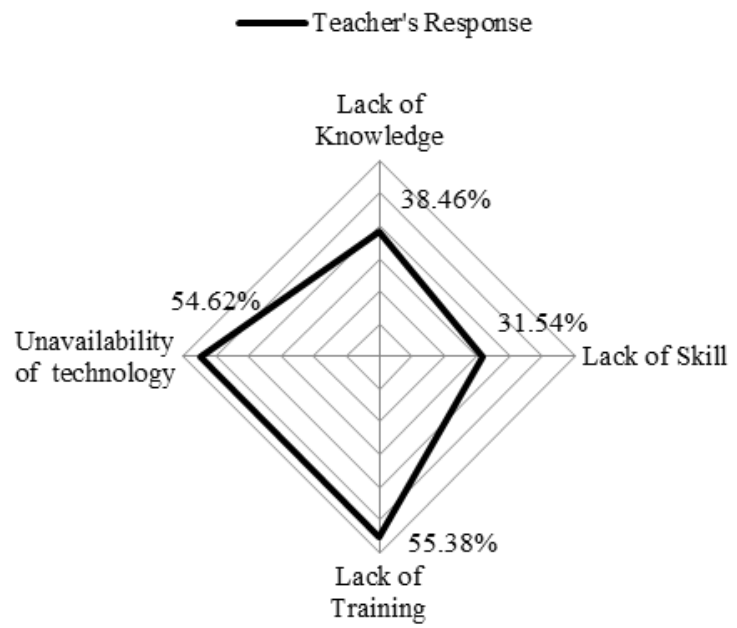

Fig. 2: Factors to limit the use of modern technology (multiple responses were accepted)

The above figure displays the value related to the center point. The center point is considered for ideal case. The more near to the center point the stronger and positive views in that particular statement. Though in teachers' responses it was found that few teachers were in thought of lacking in skill which means majority of them were in favor of having good technical skill. Moreover, they claimed that inadequate technology and insufficient training facilities were the crucial factor to make hindrance of using technology in the educational settings. Research indicates that lack of administrative and institutional support, lack of training and experience, and limitations resulting from personality or attitudinal factors often result in teachers falling short when attempting to incorporate technology [46]. Effective implementation of technology into education systems involves substantial funding, that is very hard to manage in developing countries like Bangladesh, where many people are living below the poverty line. Mumtaz [33] states that many scholars proposed that the lack of funds to get the necessary hardware and software is one of the reasons teachers do not use technology in their classes. That's why most of the administrators opined that the expenses of the technology were the vital reason over the others to limit the use of technology.

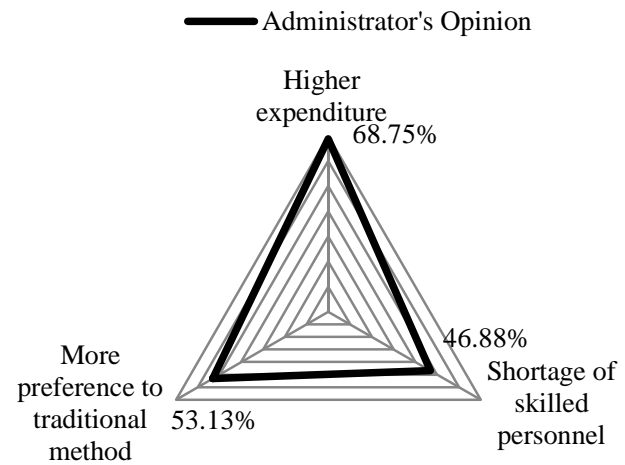

Fig. 3: Factors to limit the use of modern technology (multiple responses were accepted)

However, the shocking facet of the administrators' views was that the teacher did not have liking to use the modern technology as a first choice. They were, somehow, in favor of the conventional method as they used to. Equipping teachers with technology and then failing to provide adequate training or failing to consider curricular issues has led to technology anxiety [47]. Gardner, Discenza, and Dukes [48] determined that computer anxiety is a major cause of resistance to using computers. This and other research indicates that increased computer experience reduces computer anxiety in many teachers. However, the ability to reduce anxiety may also depend on the type of computer experience to which the teachers are exposed [49]. Lokken, Cheek, and Hastings' [50] stated that older teachers had less confidence in technology and in their ability to use technology. A lack of experience with incorporating technology in instruction was a factor that resulted in teachers avoiding the use of technology [33]. Another study reported that more experienced teachers were less likely to utilize technology than less experienced teachers [51]. Other studies also reported that technology unavailability was an important factor inhibiting the use of technology by teachers $[33,20]$. In addition, scarcity in skilled human resources was also an important factor to limit the use of technology as believed by the administrators.

\subsection{Training, Technical Complicacy and the Quality of Technology Service}

The following table illustrated the thoughts of teachers, administrators and students on need of technical training, facing technical complicacy during application and the quality of technology service the institution provided to them. 
Table-12: Opinions of teachers, students and administrators

\begin{tabular}{|c|c|c|c|}
\hline $\begin{array}{l}\text { Statements/ } \\
\text { Questions }\end{array}$ & Opinions & WA $\quad \chi_{\text {observed }}^{2}$ & $\chi_{\text {critical }}^{2}$ \\
\hline \multirow{2}{*}{$\begin{array}{l}\text { Lack of } \\
\text { understanding } \\
\text { about the need } \\
\text { of training }\end{array}$} & Teacher & $3.16 \quad 17.08$ & \multirow{7}{*}{9.488} \\
\hline & Administrator & $3.56 \quad 5.35$ & \\
\hline \multirow{2}{*}{$\begin{array}{l}\text { Modern } \\
\text { technology are } \\
\text { too } \\
\text { complicated to } \\
\text { use }\end{array}$} & Teacher & $\begin{array}{ll}2.78 & 19.92\end{array}$ & \\
\hline & Administrator & $3.22 \quad 14.57$ & \\
\hline \multirow{3}{*}{$\begin{array}{l}\text { The quality of } \\
\text { technology } \\
\text { service your } \\
\text { institution } \\
\text { receive up to } \\
\text { now }\end{array}$} & Teacher & $\begin{array}{ll}2.45 & 22.53\end{array}$ & \\
\hline & Administrator & $2.84 \quad 23.17$ & \\
\hline & Student & $3.34 \quad 40.90$ & \\
\hline \multicolumn{4}{|c|}{$\begin{array}{l}\text { Result: Null hypothesis was rejected in all the cases except the } \\
\text { Administrators' views on 'Lack of understanding about the } \\
\text { need of ICT training' where null hypothesis was accepted as } \\
\chi_{\text {observed }}^{2}<\chi_{\text {critical }}^{2}\end{array}$} \\
\hline
\end{tabular}

\subsubsection{Teachers'views}

It revealed from the table- 12 that the teachers were neither too optimistic nor too pessimistic in the first two statements. Nevertheless, in the third case, they thought that the quality of technology service the organization provided to them was below standard. In every case teachers' opinions were found significant as the null hypotheses were rejected. Thus, the teachers gave their opinions with proper knowledge.

\subsubsection{Administrators' views}

The administrators gave the affirmative responses on the first statement. It indicated that the teachers had not been aware of the need of skill training on technology. But the experimental result refuted the administrators' idea as the null hypothesis was accepted. They gave their views based on the chance factor without knowing the real situation. Regarding the second and third statements their observations was found to be significant.

\subsubsection{Students'views}

Students were not satisfied on the overall technology service they received from the institution. They responses were found average. As the null hypothesis rejected, the differences in their opinions were found significant.

Research indicates that teachers' negative attitude on the use of technology should be changed to support meaningful learning [52]. Therefore teachers need to possess a positive attitude to the use of technology. Such an attitude is developed when teachers are sufficiently comfortable with technology and are knowledgeable about its use [53, 32]. Many critics have argued that successful use of technology in schools may depend on how well schools of education model technology, provide opportunities for practice and reflection, and prepare teachers to use technology in their own classrooms [54, 55]. Research shows that overall satisfaction with the use of technology-enhanced learning is mixed [56]. The primary factors associated with higher satisfaction are faculty knowledge about the technology, their comfort in using it, and the amount of communication and interaction with faculty by the students $[57,58]$.

\section{CONCLUSION}

It would not be fair enough to draw a general inference from the above discussion, but it gives an apparent representation of the Government polytechnic institutes of Bangladesh regarding the use of technology in the educational setting. Although the impact of technology on student learning was not addressed highly in this study, it is clear that faculty and staff must adopt technology for effective instruction. It is clearly understood by this investigation that the present status does not meet up the necessity of teachers, students and administrators as well as the demand of institution. Besides few polytechnics in Bangladesh position learning rooms where teachers are asked to find out, apply, and evaluate effective technology-enriched teaching and learning practices. Some teachers do offer such activities as a self-initiative; but, these tend to be viewed as an isolated effort.

Strong professional and organizational support for technology-based instruction $[59,60]$ indicates the need to continue investigating the integration of technology in classroom instruction. The final remark is that the polytechnics should provide competency based training program on technology integration. The Government needs to work with the industry to fix the competencies, national curriculum, and then those can be evaluated by the institutions. Skill of technology would be a part of the nation building effort and strategic focus would be given greatly on technical and vocational education sector to promote the national economy.

\section{REFERENCES}

[1] Goel, V. P. (2010). Technical and Vocational Education and Training (TVET) System in India for Sustainable Development. Ministry Of Human Resource Development, Government of India, http://www.unevoc.unesco.org/up/India_Country_Paper. pdf, Accessed June, 2012

[2] Bhuiyan, S. H. (2011). Modernizing Bangladesh public administration through e-governance: Benefits and challenges. Government Information Quarterly, 28(1), 54-65

[3] Ministry of Education, (2011). Director of Technical Education, Government of the People's Republic of Bangladesh.

http://www.moedu.gov.bd/index.php?option=com_conte nt\&task=view\&id=317\&Itemid=229, Accessed January, 2012

[4] Director of Technical Education Board, (2012). http://www.techedu.gov.bd/. Accessed April, 2012

[5] Islam, T. \& Selim, A. S. M. (2006). Current Status and Prospects for E-learning in the Promotion of Distance Education in Bangladesh. Turkish Online Journal of Distance Education. 7(1), 114-123

[6] ISTE (2006). National Educational Technology Standards for Students. http://cnets.iste.org/students/s_stands.html, Accessed March, 2012

[7] Ping, L. C., Swe, K. M., Hew, T., Wong, P., and Shanti, D. (2003). Exploring critical aspects of information technologies integration in Singapore schools. Australian Journal of Educational Technology, 19 (1), 1-24 
[8] Ali, M. (2003). Education case study, ASPBAE research on information and communication technology (Bangladesh). Asian South Pacific Bureau of Adult Education (ASPBAE), Dhaka Ahsania Mission.

[9] Khan, S. (2010). ICT in Education. Orientation Workshop on Developing ICT in Education Master Plan for Bangladesh, The Ministry of Education, The Government of the People's Republic of Bangladesh, http://saburkhan.info/index.php?option=com_content\&vi ew $=$ article $\& i d=424$ : working-paper-for-ict-in-educationmaster-plan-workshop\&catid=77:e-learning \&Itemid $=73$, Accessed January, 2012

[10] Ahmad, M. \& Ahmed, M. (2002). Bangladesh Education Sector Overview. Final report, Japan Bank for International Cooperation. http://www.jica.go.jp/activities/schemes/finance_co/appr oach/pdf/eban.pdf, Accessed January, 2012

[11] Jhurree, V. (2005). Technology integration in education in developing countries: Guidelines to policy makers. International Education Journal, Shannon Research Press, 6(4), 467-483

[12] Levine, J. (1998). Planning strategically for Technology Integration. Conference Proceedings Technology and Teacher Education Annual. Charlottesville, VA, pp. 293295

[13] Papo, W. (2001). Integration of educational media in higher education large classes. Educational Media International, 38(2-3), 95-99.

[14] Means, B., Olsen, K. (1997). Technology and Education Reform. Washington, D.C.: U.S. Dept. of Education, Office of Educational Research and Improvement, Office of Reform Assistance and Dissemination.

[15] Williams, M. D. (2000). Introduction: What is technology integration? M D Williams (Ed.) Integrating Technology into Teaching and Learning: Concepts and Applications. Singapore: Prentice Hall.

[16] Twigg, C. A. (2000). Institutional readiness criteria. EDUCAUSE Review, 35(2), 42-51

[17] Szabo, M. (2000). Technical and non-technical aspects of computer based instruction. Information Technology in the Social Sciences Symposium, Baptist University, Hong Kong.

[18] Drent, M., and Meelissen, M. (2008). Which factors obstruct or stimulate teacher educators to use ICT innovatively? Computers and Education, 51 (1), 187199.

[19] Keengwe, J., G., Onchwari, et al. (2008). Computer technology integration and student learning: Barriers and promise. Journal of Science Education and technology, 17(6), 560-565.

[20] Chapman, B. F. (2006). An analysis of the factor and adoption of computer technology by business teacher educators. NABTE Review, (33), 22-28

[21] Redmann, D. H., \& Kotrlik, J. W. (2004). Analysis of technology integration in the teaching-learning process in selected career and technical education programs. Journal of Vocational Education Research, 29(1), 3-25

[22] Thomas, R., Adams, M., Meghani, N., \& Smith, M. (2002). Internet integration in high schools: Patterns, opportunities, and barriers. St. Paul, MN: National Research Center for Career and Technical Education.

[23] Anne H. M., et al. (2007). Active Learning and Technology: Designing Change for Faculty, Students, and Institutions. EDUCAUSE Review, 42(5), 42-61

[24] Donna, H. (2005). By Instructional Design: Facilitating Effective Teaching and Learning with Technology. In M. O. Thirunarayanan and Aixa Perez-Prado (ed.), Integrating Technology in Higher Education, (pp. 1945). University Press of America.

[25] The Horizon Report, (2007). For more ideas about relevant ways to use technology in teaching and learning activities, see the New Media Consortium and the EDUCAUSE Learning Initiative, The Horizon Report, Austin, Tex.: New Media Consortium.

[26] Natriello, G. (2007). Imagining, Seeking, Inventing: The Future of Learning and the Emerging Discovery Networks. Learning Inquiry, 1(1), 7-18

[27] Yonker, M. (1995). Executive Education and Leadership Development. New York: University Park, P.A.

[28] Roknuzzaman, M. (2006). A survey of Internet access in a large public university in Bangladesh University of Rajshahi, Bangladesh. International Journal of Education and Development using Information and Communication Technology (IJEDICT), 2(3), 86-105.

[29] Khan O. F. (2007). Information and Communication Technology (ICT) Status, issues and future development plans of Bangladesh. SASEC, First Meeting of ICT, Bangladesh Telecommunication Regulatory Commission.

[30] Leggett, W. P. \& Persichitte, K. A. (1998). Blood, sweat, and TEARS: 50 years of technology implementation obstacles. TechTrends, 43(3), 33-36

[31] Mangal, S., K. (2010). Statistics in Psychology and Education, New Delhi: PHL Learning Private Limited.

[32] Afshari, M., Bakar, K., A., Su Luan, W., Samah, B. A., \& Fooi, F. S. (2009). Factors affecting teachers' use of information and communication technology. International Journal of Instruction. 2(1), 77-104

[33] Mumtaz, S. (2000). Factors affecting teachers ' use of Information and Communication Technology: A review of the literature. Journal of information technology for teacher education. 9(3), 319-342

[34] BECTA, (2003). What the research says about barriers to the use of ICT in teaching. British Educational Communications and Technology Agency (BECTA). http://www.mmiweb.org.uk/publications/ict/Research_B arriers_TandL.pdf, Accessed May, 2012

[35] Laskowski, Mary S. (2002). The Role of Technology in Research: Perspectives from Students and Instructors, Libraries and the Academy, 2(2), 305-319, The Johns Hopkins University Press

[36] Phillips, J. A. (2001). Research in Teaching \& Learning in a Technology-Based Environment: Theoretical Perspectives Influencing Inquiry Methods. Proceedings of the Qualitative Research Convention: Navigating Challenges, University of Malaya.

[37] Gibbons, A.S. \& Fairweather, P.G. (1998). Computer- 
based instruction: Design and development: New Jersey: Educational Technology Publications.

[38] George, A.S., McEwin, K., \& Jenkins, J.M. (2000). The exemplary high school. New York: Harcourt

[39] Kellenberger, D.W., \& Hendricks, S. (2000). Predicting teachers' computer use for own needs, teaching and student learning. Journal of Educational Computing Research, 16(1), 53-64

[40] Gunter, G.A. (2001). Making a difference: Using emerging technologies and teaching strategies to restructure an undergraduate technology course for preservice teachers. Educational Media International, 38(1), 13-20.

[41] Kumar, N., Rose, R. C., D’Silva, J.L. (2008). Teachers' Readiness to Use Technology in the Classroom: An Empirical Study. European Journal of Scientific Research, 21 (4), 603-616

[42] Vannatta, R. A., \& Fordham, N. (2004). Teacher dispositions as predictors of classroom technology use. Journal of Research on Technology in Education, 36(3), 253-271

[43] Albee, J.J. (2003). A study of preservice elementary teachers' technology skill preparedness and examples of how it can be increased. Journal of Technology and Teacher Education, 11(1), 53-72

[44] Woodrow, J. E. (1992). The influence of programming training on the computer literacy and attitudes of preservice teachers. Journal of Research on Computing in Education, 25(2), 200-218.

[45] Berner, J. E. (2003). A study of factors that may influence faculty in selected schools of education in the Commonwealth of Virginia to adopt computers in the classroom. Abstract Doctoral Dissertation, George Mason University. ProQuest Digital Dissertations

[46] Brinkerhoff, J. (2006). Effects of a long-duration, professional development academy on technology skills, computer self-efficacy, and technology integration and beliefs. Journal of Research on Technology in Education, 39(1), 22-43

[47] Budin, H. (1999). The computer enters the classroom. Teachers College Record, 100(3), 656-669.

[48] Gardner, D. G., Discenza, R., \& Dukes, R. L. (1993). The measurement of computer attitudes: An empirical comparison of available scales. Journal of Educational Computing Research, 9(4), 487-507
[49] McInerney, V., McInerney, D. M., \& Sinclair, K. E. (1994). Student teachers, computer anxiety and computer experience. Journal of Educational Computing Research, 11(1), 27-50

[50] Lokken, S. L., Cheek, W. K., \& Hastings, S. W. (2003) The impact of technology training on family and consumer sciences teacher attitudes toward using computers as an instructional medium. Journal of Family and Consumer Sciences Education, 21(1), 18-32

[51] Smerdon, B., Cronen, S., Lanahan, L., Anderson, J., Iannotti, N. \& Angeles, J. (2000). Teachers' tools for the 21st century: A report on teachers' use of technology. Washington, D.C.: National Center for Education Statistics, U.S. Department of Education.

[52] Novak, J. D. (1998). Learning, creating, and using knowledge: concept maps as facilitative tools in schools and corporations. Mahawah, NJ: Lawrence Erlbaum Associates.

[53] Harrison, A. W. and Rainer, R. K. (1992). The influence of individual differences on skill in End-user Computing. Journal of Management Information Systems, 9(1), 93111

[54] Kent, T. W., \& McNergney, R. F. (1999). Will technology really change education?: From blackboard to web. Thousand Oaks:Corwin.

[55] Pellegrino, J. W. \& Altman, J. E. (1997). Information technology and teacher preparation: Some critical issues and illustrative solutions. Information Technology and Teacher Preparation, 72(1), 89-121

[56] Bloom, K. C. \& Hough, M. C. (2003). Student Satisfaction with Technology enhanced Learning. CIN: Computers, Informatics, Nursing, 21(5), 241-246

[57] Baldwin D, Johnson J, Hill P. (1994). Student satisfaction with classroom use of computer-assisted instruction. Nurs Outlook, 42:188-192

[58] Sole, M. L, Lindquist, M. (2001). Enhancing traditional, televised, and videotaped courses with Web-based technologies: a comparison of student satisfaction. Nurs Outlook, 49:132-137

[59] Bower, B. L. (1998). Instructional computer use in the community college: A discussion of the research and its implications. Journal of Applied Research in the Community College, 6(1), 59-66

[60] No Child Left Behind Act of 2001, Pub No. 107-1105. (2001).Washington, DC: U. S. Congress. 